\title{
The Influence of Tree Structural and Species Diversity on Temperate Forest Productivity and Stability in Korea
}

\author{
Juhan Park ${ }^{1,2}$, Hyun Seok Kim ${ }^{1,2,3,4, * \mathbb{C}}$, Hyun Kook Jo ${ }^{5}$ and II Bin Jung ${ }^{5}$ \\ 1 National Center for Agro-Meteorology, Seoul 08826, Korea; ecohani@gmail.com \\ 2 Department of Forest Sciences, Seoul National University, Seoul 08826, Korea \\ 3 Interdisciplinary Program in Agricultural and Forest Meteorology, Seoul National University, \\ Seoul 08826, Korea \\ 4 Research Institute for Agriculture and Life Sciences, Seoul National University, Seoul 08826, Korea \\ 5 Forest Resources Information Division, Korea Forest Promotion Institute, Seoul 07570, Korea; \\ hcho@kofpi.or.kr (H.K.J.); leohunter@kofpi.or.kr (I.B.J.) \\ * Correspondence: cameroncrazies@snu.ac.kr
}

Received: 17 October 2019; Accepted: 5 December 2019; Published: 6 December 2019

\begin{abstract}
Research Highlights: Using a long-term dataset on temperate forests in South Korea, we established the interrelationships between tree species and structural diversity and forest productivity and stability, and identified a strong, positive effect of structural diversity, rather than tree species diversity, on productivity and stability. Background and Objectives: Globally, species diversity is positively related with forest productivity. However, temperate forests often show a negative or neutral relationship. In those forests, structural diversity, instead of tree species diversity, could control the forest function. Materials and Methods: This study tested the effects of tree species and structural diversity on temperate forest productivity. The basal area increment and relative changes in stand density were used as proxies for forest productivity and stability, respectively. Results: Here we show that structural diversity, but not species diversity, had a significant, positive effect on productivity, whereas species diversity had a negative effect, despite a positive effect on diversity. Structural diversity also promoted fewer changes in stand density between two periods, whereas species diversity showed no such relation. Structurally diverse forests might use resources efficiently through increased canopy complexity due to canopy plasticity. Conclusions: These results indicate reported species diversity effects could be related to structural diversity. They also highlight the importance of managing structurally diverse forests to improve productivity and stability in stand density, which may promote sustainability of forests.
\end{abstract}

Keywords: temperate forest; species diversity; structural diversity; basal area increment; stability; structural equation model

\section{Introduction}

The relationships between productivity and species diversity are one of the oldest questions in ecological studies. For the last two decades, this relationship has been intensively investigated [1-3]. However, considerable variations and controversy in this relationship still remain, and the mechanisms underlying this relationship are not yet fully understood.

The complementarity hypothesis links species diversity and productivity. It assumes that productivity increases with species number through positive interactions such as competition reduction or facilitation among species. By comparison, facilitation occurs when a species improves the growing conditions for another species through processes such as nitrogen fixation [4] and hydraulic 
redistribution [5]. Competition reduction occurs when a species is introduced to a stand that has intense intra-specific competition, and replaces it with less intense inter-specific competition though the processes such as stratification of the root system or canopy [6]. However, it is unknown whether the positive effects of species diversity on productivity applies in forests, as the majority of evidence on the relationship has been found on grasslands [1,7].

The evidence for positive effects of tree species diversity on forest productivity has been accumulating [8,9], but negative or neutral effects of tree species diversity on productivity have also been reported $[10,11]$. Despite the recent findings of the positive relationship between tree species diversity and forest productivity $[12,13]$, there are remaining questions as to why different relationships are observed, especially in temperate forests $[8,11]$. These might be caused by functional redundancy and overlap of niches among coexisting tree species [14], and different diversity measures, such as functional or phylogenic diversity, have been considered to explain the diversity-productivity relationship. Unlike short-lived ecosystems such as grasslands, forests are composed of long-lived tree species with large inter- and intra-specific size differences. This heterogeneity in tree size might have similar effects to species diversity, as trees of different sizes among the same species can occupy different niches. Therefore, structural diversity is considered as a dominant factor in forest productivity and standing biomass $[15,16]$.

Species and structural diversity can also be inter-correlated, as species diversity increases structural diversity when species with different life strategies coexist. Species diversity can also promote tree size and canopy height heterogeneity as well [17], while structural diversity can be a proxy for species diversity. Thus, species diversity indirectly affects productivity via structural diversity. This could explain the positive relationship between them at a global scale. However, structural diversity could negatively affect productivity in monocultures $[18,19]$, and have opposing effects in mixed stands $[16,20]$. Therefore, the underlying mechanism of diversity and productivity remains debated.

The species and structural diversity also affects forest stability. However, the effects of diversity on forest ecosystem stability are rarely examined, partly as forest stability can be defined in multiple ways, including resistance, resilience, constancy, and persistence in either or both functional and structural aspects [21], which causes divergence within the field [22]. In addition, the diversity-stability relationship could be connected to the diversity-productivity relationship. Two main mechanisms for the diversity-stability relationship are proposed-asynchrony and over-yielding [23]. Asynchrony, which indicates an imperfect correlation in species responses to stress and disturbance, mitigates the negative effects of disturbance and decreases the overall variation in ecosystems. Over-yielding, which occurs when a mixed species forest has higher productivity than the sum of expected productivity of each species, is facilitated by niche partitioning [24], and increases forest stand resistance against disturbance.

Thus, this study aims to find dominant factors influencing forest productivity and stability in temperate forests. By using National Forest Inventory (NFI) data collected in South Korea at 5-year intervals, we constructed a structural equation model (SEM) to test the direct and indirect effects of species and structural diversity on forest productivity. We hypothesized that: 1 . species diversity would have positive effects on stand productivity, but be mediated via structural diversity; 2 . structural diversity would have a stronger effect than species diversity on stand productivity; and 3 . forest stability would increase as species and structural diversity increased.

\section{Materials and Methods}

\subsection{Study Area and Inventory Method}

This study was confined to the temperate forests in South Korea $\left(33.16^{\circ} \mathrm{N}-38.61^{\circ} \mathrm{N}\right.$, $\left.124.59^{\circ} \mathrm{E}-130.92^{\circ} \mathrm{E}\right)$. Despite the diversity in size, these forests also had relatively diverse tree species, where on average, 12 tree species and up to 32 tree species coexisted, and were dominated by broad-leaved Quercus spp. and coniferous Pinus species. Korean National Forest Inventory data from 3959 permanent plots were used, which covered various stand ages and densities, management 
intensities, and environmental conditions, including diameter at breast height (DBH), and estimated height by species-specific allometric equations for more than 700,000 trees. The NFI is a 5-year interval survey and the most recent two data periods (5th NFI during 2006-2010 and 6th NFI during 2011-2015) were used for the study.

The NFI plots consisted of a single main survey plot and three subplots located on the northern, southeastern, and southwestern sides, at a 50-m distance (Figure 1). The NFI provided regionally validated data across a wide range of spatial and temporal conditions, which monitored the long-term changes in forest stands at a large spatial scale. However, to reduce the observational errors, plots with extreme changes ( $>97.5$ th quantile) in relative stand density and basal area increments were excluded from the analysis, as the NFI did not provide full details of each site history.

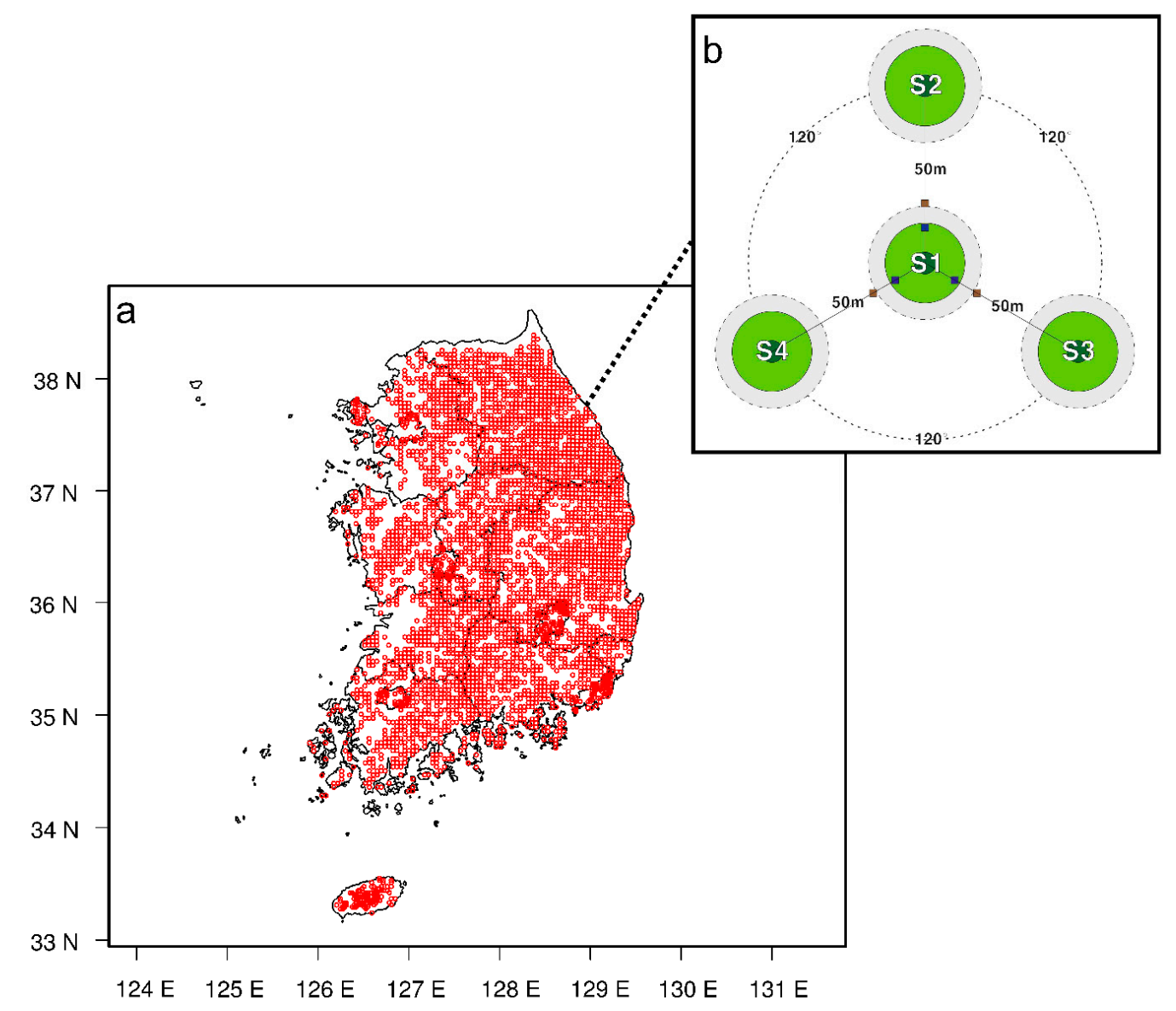

Figure 1. National Forest Inventory plots used in this study and their distribution across South Korea.

Panel b shows the structure of the cluster plot.

\subsection{Forest Productivity Estimation}

Forest productivity was calculated at the stand level, due to limitations in NFI data for tracking individual tree growth. Stand productivity was assumed as the differences in the sum of all individual tree basal areas between the two survey periods:

$$
B A I_{\text {stand }}=\sum B A 6_{\text {Tree }}-\sum B A 5_{\text {Tree }}
$$

where $B A I_{\text {stand }}$ is the stand basal area increment, $B A 6_{\text {Tree }}$ is the basal area of individual trees in the 6th NFI period, and $B A 5_{\text {Tree }}$ is the basal area of individual trees in the 5 th NFI period. The productivity analysis excluded plots with negative $B A I_{\text {stand }}$, and a total of 3151 plots were analysed. 


\subsection{Tree Species and Size Diversity}

Tree species diversity $\left(H_{S p}\right)$ and structural diversity were separated for the analysis. The stand structural diversity $\left(H_{D B H}\right)$ was quantified depending on variability of tree diameter. Both species and structural diversities were calculated using the Shannon diversity index [25]:

$$
\begin{gathered}
H_{S p}=-\sum_{i=i}^{n} p_{i} \times \ln \left(p_{i}\right) \\
H_{D B H}=-\sum_{j=i}^{m} p_{j} \times \ln \left(p_{j}\right)
\end{gathered}
$$

where $n$ is the total number of species in the stand, $p_{i}$, is the proportion of basal area for species $i, m$ is the total number of DBH classes in the stand, and $p_{j}$, is the proportion of basal area for DBH class $j$. DBH was classified in intervals of $3 \mathrm{~cm}$, as this interval showed the highest correlation with stand basal area increment. Tree height and the spatial arrangement of trees was not considered in this study due to the lack of availability of height data and absence of tree coordinates. Due to high correlation among tree diameter and height (Figure S1), horizontal variability could be linked with vertical variability, which makes tree diameter variability possible to use as proxy of forest structural diversity. Other horizontal structural diversity indices, such as the coefficient of variation $(\mathrm{CV})$, skewness, and closeness to a J-shaped distribution of DBH were not included in the analysis due to their lower correlation with productivity. Species richness (SR) was calculated using the total number of species in each plot. The stand basal area, species richness, species diversity, and structural diversity were classified into 10 groups based on their values (group intervals were 1.5 for stand basal area, 3 for species richness, and 0.3 for species and structural diversity).

\subsection{Environmental Conditions}

The environmental conditions for each plot were derived from the digital climate model (DCM). The DCM generated hyper-resolution $(270 \mathrm{~m})$ gridded digital reanalysis data for 30-year-averaged monthly mean air temperature and precipitation by considering landscape topographical characteristics [26,27]. Two environmental variables-annual mean air temperature and annual precipitation-were considered as main controlling factors in species and structural diversity and forest productivity. Each environmental variable was classified into three groups by quantiles, and the correlation coefficient between species and structural diversity and productivity was determined within each class.

\subsection{Structural Equation Modelling}

The effects of species and structural diversity can be separated using structural equation modelling (SEM), which identifies the interconnections and causal relationships among variables. Species diversity was assumed to have indirect effects on forest productivity via structural diversity. To test this hypothesis, we used SEM to estimate direct and indirect effects of species and structural diversity on stand BAI. The SEM in this study used a combination of factor analysis and path analysis, which did not include latent variables. This model was suitable for analysing the complex systems, while not assuming independence among variables. The causal relationships between variables were assumed to be recursive. We constructed a single SEM model that included basal area, structural diversity, and species diversity as predictors of stand BAI (Figure 2). This model represented the partial mediation of species diversity effects, so that species diversity could have both direct and indirect effects on productivity. Structural diversity was assumed to have only direct effects on productivity. We report standardized path coefficients to facilitate comparisons between pathways. The SEM was implemented using the lavaan packages [28] in $R$ software. 


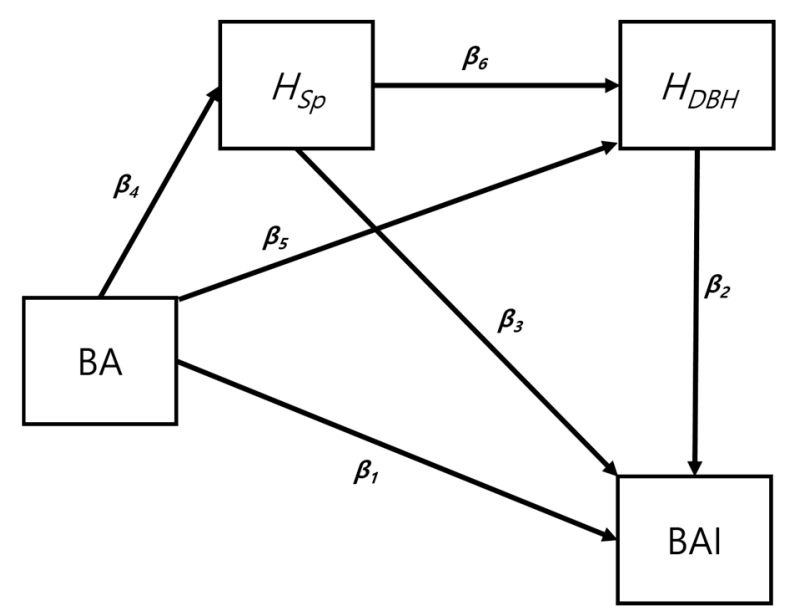

Figure 2. Schematic representation of the structural equation model used in the analysis. BA, $H_{S p}$, $H_{D B H}$ and BAI stand for basal area, tree species diversity, structural diversity and basal area increment, respectively.

\subsection{Forest Stability}

In this study, forest stability was assumed to indicate consistency, and was evaluated from the structural aspect only. Because, in natural forests, changes in stand density are caused by differences in regeneration and death rate, and are usually accompanied by changes in stand structural properties like diameter distribution and species composition [29], the relative changes in stand density ( $\Delta \mathrm{SD})$ between the two survey periods were used as a proxy of forest stability. Firstly, all the NFI data was divided into two groups depending on an increase (3238 plots) or decrease (632 plots) in stand density. In each dataset, changes in stand density were divided by stand density in the 5th NFI period, and the relative change in stand density was compared with species and structural diversity indices. Plots with drastic changes ( $>97.5$ th quantile) were considered to be affected by forest management practices, such as thinning, or natural disasters, and were excluded in the analysis. Plots with smaller changes in stand density were considered as more stable.

\section{Results}

Forest productivity was mostly affected by stand basal area, and the diversity-productivity relationship differed by index. It increased significantly with stand basal area and structural diversity, but decreased significantly with species diversity. Species richness had no effect on productivity (Figure 3). The regression lines were expressed as $B A I_{\text {stand }}=0.0085 B A_{\text {stand }}+0.1162, B A I_{\text {stand }}=$ $-0.0058 H_{S p}+0.1575$, and $B A I_{\text {stand }}=0.0336 H_{D B H}+0.0756$, respectively. Stand basal area was positively correlated with both species richness $(n=3157, r=0.24, p<0.001)$ and structural diversity $(r=0.61$, $p<0.001)$, but was negatively correlated with species diversity $(r=-0.08, p<0.0001)$. Species diversity showed a positive correlation with structural diversity $(r=0.21, p<0.001)$ (Figure S2).

The diversity-productivity relationships were changed by stand basal area condition. Where stand basal area was less than $3 \mathrm{~m}^{2}$ per plot, both tree species and structural diversity had a positive relationship with productivity, but structural diversity had a more sensitive and significant relationship than species diversity. Under the intermediate condition, where stand basal area was higher than $3 \mathrm{~m}^{2}$ per plot and lower than $6 \mathrm{~m}^{2}$ per plot, the species and structural diversity had the opposite relationship with productivity. The species diversity-productivity relationship became negative as stand basal area increased. Conversely, structural diversity still had a positive effect on productivity, but the strength of the relationship was weaker than the lower stand basal area condition. Where stand basal area was higher than $6 \mathrm{~m}^{2}$ per plot, the positive diversity-productivity relationship disappeared. The negative effects of species diversity on productivity increased and there was no significant relationship between structural diversity and productivity (Figure 4). The regression lines 
were expressed as: $B A I_{\text {stand }}=0.0174 H_{S p}+0.1084$ and $B A I_{\text {stand }}=0.0188 H_{D B H}+0.0942$, when $B A_{\text {stand }}$ was lower than $3 \mathrm{~m}^{2} ; B A I_{\text {stand }}=-0.0131 H_{S p}+0.1733$ and $B A I_{\text {stand }}=0.0143 H_{D B H}+0.1227$, when $B A_{\text {stand }}$ was higher than $3 \mathrm{~m}^{2}$ and lower than $6 \mathrm{~m}^{2}$; and $B A I_{\text {stand }}=-0.0404 H_{S p}+0.2238$ when $B A_{\text {stand }}$ was higher than $6 \mathrm{~m}^{2}$.

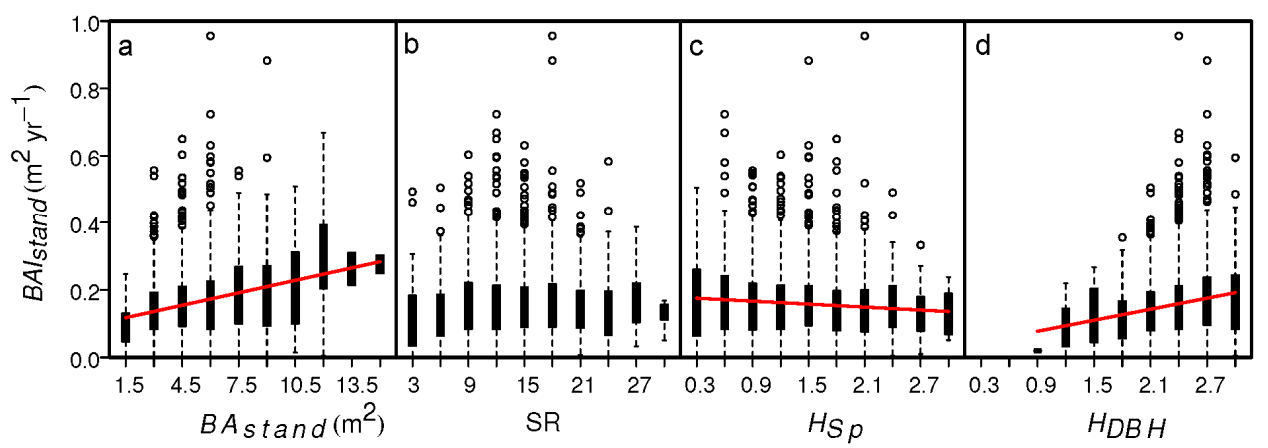

Figure 3. The effects of (a) stand basal area $\left(B A_{\text {stand }}\right)$, (b) species richness (SR), (c) species diversity $\left(H_{S p}\right)$, and $(\mathbf{d})$ structural diversity $\left(H_{D B H}\right)$ on mean annual basal area increment $\left(B A I_{\text {stand }}\right)$. Red lines indicate statistically significant relationships between $B A I_{\text {stand }}$ and each variable $(p<0.001)$.

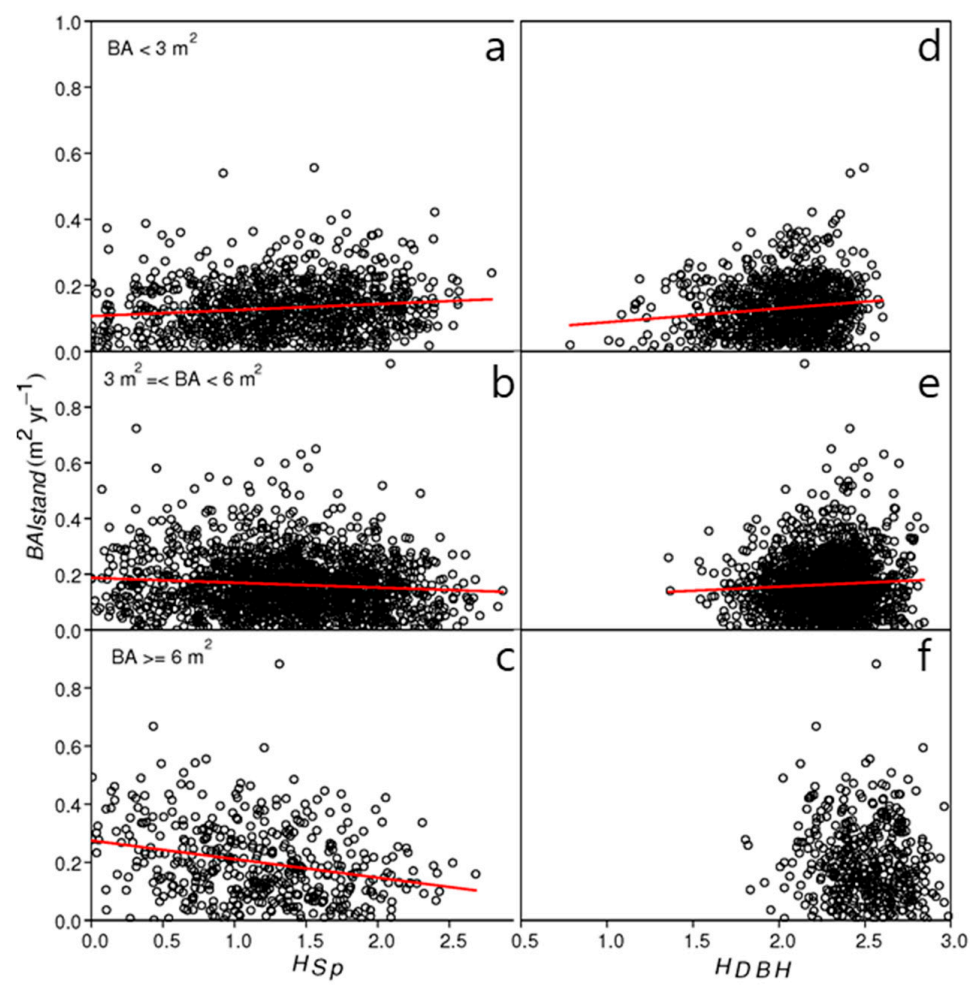

Figure 4. Changes in the diversity and productivity relationship by stand basal area $\left(B A_{\text {stand }}\right)$. Left panels $(\mathbf{a}-\mathbf{c})$ show the relationship between stand basal increment $\left(B A I_{\text {stand }}\right)$ and species diversity $\left(H_{S p}\right)$, and right panels $(\mathbf{d}-\mathbf{f})$ show the relationship between $B A I_{\text {stand }}$ and structural diversity $\left(H_{D B H}\right)$ in low (top; where BA was lower than $3 \mathrm{~m}^{2}$ ), intermediate (middle; where BA was higher than $3 \mathrm{~m}^{2}$ and lower than $6 \mathrm{~m}^{2}$ ), and high (bottom; where BA was higher than $6 \mathrm{~m}^{2}$ ) $B A_{\text {stand }}$ plots.

The slope between productivity and diversity indices was changed by environmental conditions (Figure 5). The positive relationship between productivity and structural diversity was strongest on plots under high annual mean temperature conditions, but was highest at intermediate precipitation conditions. Conversely, the negative relationship between productivity and species diversity was strongest on low air temperature conditions, but the trend was opposite with precipitation. 


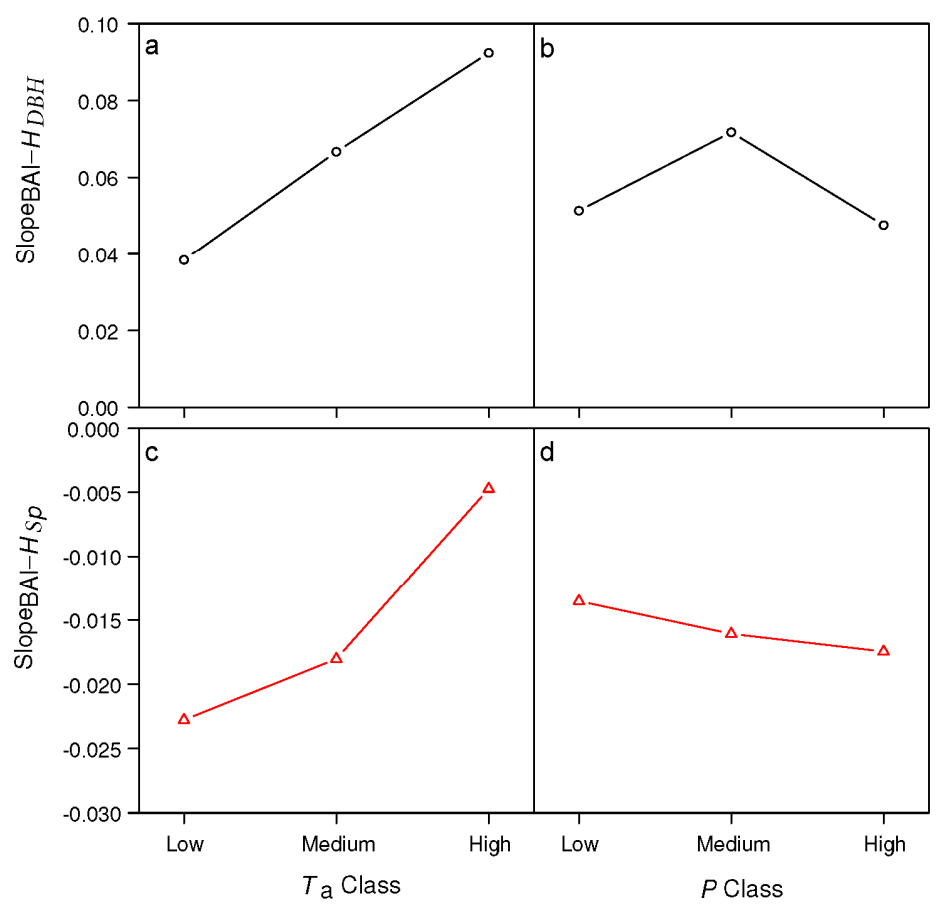

Figure 5. Changes in slope between (a) productivity and structural diversity ( $H_{D B H}$; top) by annual mean air temperature, and (b) productivity and species diversity by annual mean air temperature $\left(H_{S p}\right.$; bottom), (c) productivity and structural diversity by annual precipitation, and (d) productivity and species diversity by annual precipitation. Red indicates negative values.

Figure 6 shows that stand basal area and structural diversity had direct positive effects on stand productivity $(\beta=0.26$ and 0.09 , respectively, both $p<0.001)$, but species diversity showed a negative direct effect $(\beta=-0.09, p<0.01)$. Stand basal area also had a direct effect on structural diversity $(\beta=0.61, p<0.01)$, but a negative effect on species diversity. The correlation between basal area and species diversity was negative and the opposite correlation was found in structural diversity (Figure S2), where it had a positive indirect influence on stand productivity. Species diversity had a positive indirect effect via structural diversity $(\beta=0.26, p<0.001)$.

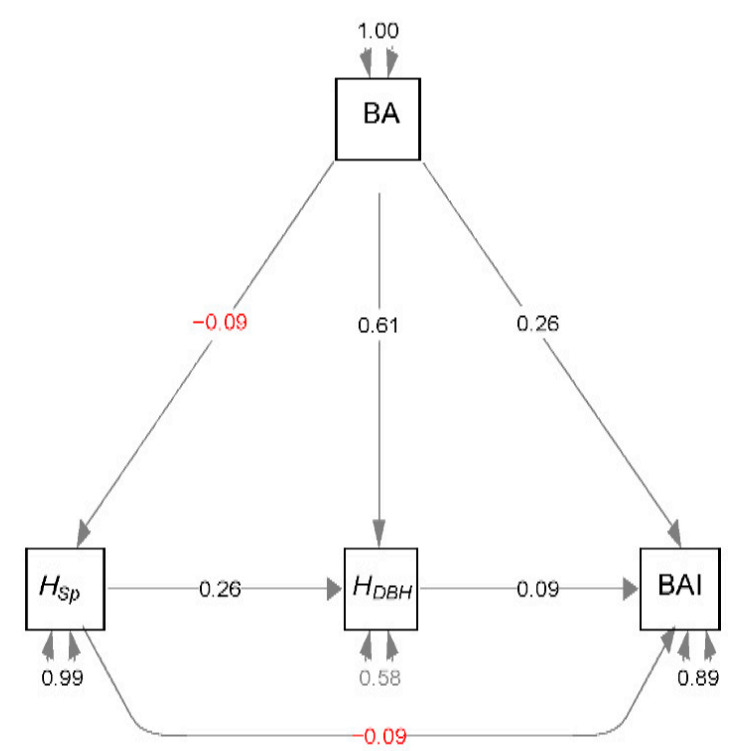

Figure 6. Structural equation model relating stand basal area increment $\left(B A I_{\text {stand }}\right)$ to stand basal area (BA $\left.A_{\text {stand }}\right)$, species diversity $\left(H_{S p}\right)$, and structural diversity $\left(H_{D B H}\right)$. Solid arrows represent significant $(p<0.05)$ paths and standardized regression coefficients are shown. The red numbers indicate the negative effects. 
Structural diversity had a significantly positive effect on forest stability, but species diversity showed no such relationship (Figure 7). As structural diversity increased, the relative increment of stand density decreased and the relative decrement of stand density also decreased. The regression lines were expressed as: $\Delta S D=-0.0376 H_{D B H}+0.4721$ in plots with positive $\Delta S D$, and $\Delta S D=0.0273 H_{D B H}-$ 0.4121 in plots with negative $\triangle S D$. This resulted in less temporal variation in stand density (between the two survey periods) on more structurally diverse plots. Conversely, species diversity did not have an impact either on relative increment of stand density, or on relative decrement of stand density.

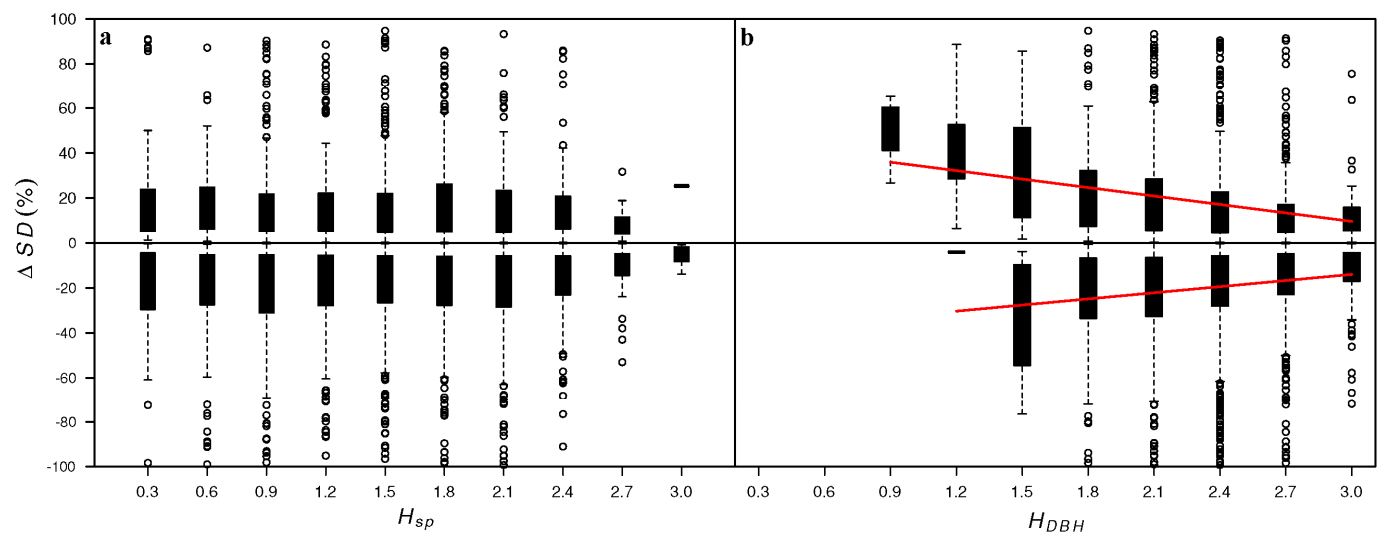

Figure 7. Changes in relative stand density $(\triangle S D)$ by (a) species diversity $\left(H_{S p}\right)$ and (b) structural diversity $\left(H_{D B H}\right)$. Red lines indicate linear regression lines between $H_{D B H}$ and $\triangle S D(p<0.001)$.

\section{Discussion}

The results of this study showed that structural diversity had a stronger effect than species diversity on forest productivity. Similarly, in mixed, uneven-aged forests in Germany, structural diversity had a profound effect on forest stand productivity, whereas species diversity effects were partially mediated via structural diversity [16]. The positive interaction between structural diversity and productivity was also found in a spruce-dominated forest in Canada [20,30]. Conversely, structural diversity has been shown to have a negative effect on productivity in coniferous forests [31] and also in deciduous forests $[19,32]$. Insignificant interactions in stand structure and productivity were also reported [33]. The variation in interactions between structural diversity and productivity may partly be caused by differences in the methods used to estimate the degree of structural diversity, but are mainly caused by complex interactions among species diversity, structural diversity, and stand characteristics. For example, structural diversity caused up to a $13 \%$ reduction in stand productivity via management techniques [34], which induced less competition for water and nutrients and low light use efficiency of small trees under limited interaction with neighboring trees.

The positive effects of structural diversity on stand productivity could have been caused by a high degree of canopy complexity, which is a potential driver of forest productivity $[35,36]$. Due to the significant correlation between tree diameter and height (Figure S1), the plots with higher structural diversity in this study might have more diverse height distribution. A diverse canopy structure enables more light penetration to understory species, which maintains greater stand total leaf area and increases stand productivity. Canopy complexity can also enhance photosynthetic efficiency. When leaf area driven increases in stand productivity reach a plateau, stand productivity continuously increases with canopy roughness [37]. Canopy complexity and structural diversity can occur through plasticity, when species adjust crown allometry to maximize light interception [38,39].

In temperate forests, species diversity may control productivity differently via structural diversity. There are many underlying processes that are related to stand structural and species compositional attributes. Enhanced productivity via nitrogen fixation is correlated more with species composition, which is more related to species identity, such as nitrogen fixing capacity, than to species diversity. A positive interaction between complementarity and stand density [40] is more sensitive to structural 
than species diversity. The relative contributions of two different types of diversity to reducing competition in productivity determines the direction of diversity-productivity interactions [41]. The most productive forests include mono species Eucalyptus plantations, which are managed as monocultures to increase productivity. Similarly, the maximum productivity was decreased with species richness in European temperate forests [42]. In Korea, a long history of reforestation has resulted in nation-wide distribution of monocultures and even-aged forests. These include middle-aged Larix forests, which have higher productivity than mixed forests. Species diversity cannot improve productivity in a stand that is near its optimum efficiency. Forest management practices, such as pruning and fertilization, lessen competition, and reduce the sensitivity to species diversity. Otherwise, species diversity could be increased under poor site conditions, where open canopy conditions enable the mixture of small tree species with lower productivity [43]. This would also cause a negative correlation between species diversity and stand basal area. In addition, it is possible that the species diversity index did not capture the entire range of shade tolerances nor account for the effect of vertical crown stratification. The structural diversity index could have better reflected the ability to quickly and efficiently fill new gaps more than species diversity.

Stand basal area can significantly affect the diversity and productivity relationship. When stand basal area is low, any interactions among trees are weak, and intensify as stand basal area increases; however, the interaction direction can change with site conditions. Changes in direction of interactions between diversity and productivity are determined by the relative strength of the complementarity effect [44] and competition intensity $[45,46]$, with increasing stand density or basal area. The diversity-productivity relationship can also be changed depending on the environmental conditions. In this study, the slope between structural or species diversity and productivity changed by air temperature and precipitation conditions, and the changes by air temperature were more significant than precipitation. Although air temperature had little influence on productivity, it negatively affected both species and structural diversity. Conversely, precipitation has a positive relationship with productivity, species, and structural diversity (Table S1).

The stability in stand density was increased with structural diversity, but was not affected by species diversity. Even though stability in stand density does not represent the whole stability of a forest stand, the results contradict previous studies that reported a positive association between species diversity and stability $[47,48]$. The positive relationship is mainly dependent on asynchronous species responses to environmental fluctuations and an increased possibility of over-yielding by species mixture [49]. The higher stability of stand density in structurally diverse forests could cause increased productivity. The long-term productivity of a forest is closely linked to its internal nutrient cycling [50,51], with structurally stable forests having higher buffer capacity [52]. Because buffer capacity includes storage capacity for water and nutrients, and resistance to acidification and nutrient leaching, structurally diverse forests have increased biogeochemical stability, which would lead to higher productivity under various stress conditions.

\section{Conclusions}

Forest structural diversity promoted both productivity and stability in stand density of temperate forests. Although species diversity had an overall negative effect on productivity and a neutral effect on stability in stand density, it had an indirect positive effect on productivity via structural diversity. Due to the large heterogeneity of the stand condition and sensitivity of the diversity-productivity relationship on climatic conditions, these results do not confirm the general rule of higher productivity in less species-diverse forests. Rather, they indicate that in temperate forests, structural diversity is a key contributor of forest sustainability by promoting productivity and stability in stand density. Therefore, forest management planning should focus on creating structurally diverse forests.

Supplementary Materials: The following are available online at http://www.mdpi.com/1999-4907/10/12/1113/s1, Figure S1: The relationship between tree diameter at breast height (DBH) and measured tree height from 5th National Forest Inventory data $(r=0.65, p<0.0001)$, Figure S2: Correlation plots among stand density (SD), stand 
basal area $(\mathrm{BA})$, species richness $(\mathrm{SR})$, species diversity $\left(H_{S p}\right)$, structural diversity $\left(H_{D B H}\right)$, and basal area increment (BAI). Numbers indicates Pearson's correlation coefficients and asterisks indicate statistical significance $\left({ }^{*} p<0.05\right.$, $\left.{ }^{* *} p<0.01,{ }^{* * *} p<0.001\right)$, Table S1: Correlation table between environmental conditions (air temperature $\left(T_{\mathrm{A}}\right)$, and precipitation $(p))$ and stand characteristics (species diversity $\left(H_{S p}\right)$, structural diversity $\left(H_{D B H}\right)$, and basal area increment (BAI)).

Author Contributions: Conceptualization: J.P.; Formal Analysis: J.P.; Data curation: H.K.J., I.B.J.; Writing-original draft: J.P. and H.S.K.; Visualization: J.P.; Supervision: H.S.K.; Project Administration: H.S.K.; Funding acquisition: H.S.K.

Funding: This research was supported by Korea Forest Service (S211315L020120, S111215L020110), Promising-Pioneering Researcher Program through Seoul National University (SNU) in 2015, and Seoul National University Big Data Institute through the Data Science Research Project 2016.

Acknowledgments: We would like to acknowledge the extensive efforts of NFI field crews and staff for collecting, curating, and distribute the field measurement data used in this study.

Conflicts of Interest: The authors declare no conflict of interest.

\section{References}

1. Hector, A.; Schmid, B.; Beierkuhnlein, C.; Caldeira, M.; Diemer, M.; Dimitrakopoulos, P.; Finn, J.; Freitas, H.; Giller, P.; Good, J. Plant diversity and productivity experiments in European grasslands. Science 1999, 286, 1123-1127. [CrossRef] [PubMed]

2. Hooper, D.U.; Chapin, F.S.; Ewel, J.J.; Hector, A.; Inchausti, P.; Lavorel, S.; Lawton, J.H.; Lodge, D.M.; Loreau, M.; Naeem, S.; et al. Effects of biodiversity on ecosystem functioning: A consensus of current knowledge. Ecol. Monogr. 2005, 75, 3-35. [CrossRef]

3. Reiss, J.; Bridle, J.R.; Montoya, J.M.; Woodward, G. Emerging horizons in biodiversity and ecosystem functioning research. Trends Ecol. Evol. 2009, 24, 505-514. [CrossRef] [PubMed]

4. Forrester, D.I.; Bauhus, J.; Cowie, A.L.; Vanclay, J.K. Mixed-species plantations of Eucalyptus with nitrogen-fixing trees: A review. For. Ecol. Manag. 2006, 233, 211-230. [CrossRef]

5. Zou, C.; Barnes, P.; Archer, S.; McMurtry, C. Soil moisture redistribution as a mechanism of facilitation in savanna tree-shrub clusters. Oecologia 2005, 145, 32-40. [CrossRef]

6. Riofrío, J.; del Río, M.; Pretzsch, H.; Bravo, F. Changes in structural heterogeneity and stand productivity by mixing Scots pine and Maritime pine. For. Ecol. Manag. 2017, 405, 219-228. [CrossRef]

7. Tilman, D.; Reich, P.B.; Knops, J.; Wedin, D.; Mielke, T.; Lehman, C. Diversity and productivity in a long-term grassland experiment. Science 2001, 294, 843-845. [CrossRef]

8. Edgar, C.B.; Burk, T.E. Productivity of aspen forests in northeastern Minnesota, USA, as related to stand composition and canopy structure. Can. J. For. Res. 2001, 31, 1019-1029. [CrossRef]

9. Gamfeldt, L.; Snäll, T.; Bagchi, R.; Jonsson, M.; Gustafsson, L.; Kjellander, P.; Ruiz-Jaen, M.C.; Fröberg, M.; Stendahl, J.; Philipson, C.D. Higher levels of multiple ecosystem services are found in forests with more tree species. Nat. Commun. 2013, 4, 1340. [CrossRef]

10. Cavard, X.; Bergeron, Y.; Chen, H.Y.; Pare, D. Mixed-species effect on tree aboveground carbon pools in the east-central boreal forests. Can. J. For. Res. 2010, 40, 37-47. [CrossRef]

11. Chen, H.Y.H.; Klinka, K. Aboveground productivity of western hemlock and western redcedar mixed-species stands in southern coastal British Columbia. For. Ecol. Manag. 2003, 184, 55-64. [CrossRef]

12. Zhang, Y.; Chen, H.Y.H.; Reich, P.B. Forest productivity increases with evenness, species richness and trait variation: A global meta-analysis. J. Ecol. 2012, 100, 742-749. [CrossRef]

13. Liang, J.; Crowther, T.W.; Picard, N.; Wiser, S.; Zhou, M.; Alberti, G.; Schulze, E.D.; McGuire, A.D.; Bozzato, F.; Pretzsch, H.; et al. Positive biodiversity-productivity relationship predominant in global forests. Science 2016, 354. [CrossRef] [PubMed]

14. Loreau, M.; Naeem, S.; Inchausti, P.; Bengtsson, J.; Grime, J.; Hector, A.; Hooper, D.; Huston, M.; Raffaelli, D.; Schmid, B. Biodiversity and ecosystem functioning: Current knowledge and future challenges. Science 2001, 294, 804-808. [CrossRef]

15. Fotis, A.T.; Murphy, S.J.; Ricart, R.D.; Krishnadas, M.; Whitacre, J.; Wenzel, J.W.; Queenborough, S.A.; Comita, L.S. Aboveground biomass is driven by mass-ratio effects and stand structural attributes in a temperate deciduous forest. J. Ecol. 2017, 106, 561-570. [CrossRef] 
16. Danescu, A.; Albrecht, A.T.; Bauhus, J. Structural diversity promotes productivity of mixed, uneven-aged forests in southwestern Germany. Oecologia 2016, 182, 319-333. [CrossRef]

17. Morin, X.; Fahse, L.; Scherer-Lorenzen, M.; Bugmann, H. Tree species richness promotes productivity in temperate forests through strong complementarity between species. Ecol. Lett. 2011, 14, 1211-1219. [CrossRef]

18. Cordonnier, T.; Kunstler, G. The Gini index brings asymmetric competition to light. Perspect. Plant Ecol. Evol. Syst. 2015, 17, 107-115. [CrossRef]

19. Ryan, M.G.; Stape, J.L.; Binkley, D.; Fonseca, S.; Loos, R.A.; Takahashi, E.N.; Silva, C.R.; Silva, S.R.; Hakamada, R.E.; Ferreira, J.M. Factors controlling Eucalyptus productivity: How water availability and stand structure alter production and carbon allocation. For. Ecol. Manag. 2010, 259, 1695-1703. [CrossRef]

20. Lei, X.; Wang, W.; Peng, C. Relationships between stand growth and structural diversity in spruce-dominated forests in New Brunswick, Canada. Can. J. For. Res. 2009, 39, 1835-1847. [CrossRef]

21. Holling, C.S. Resilience and stability of ecological systems. Annu. Rev. Ecol. Syst. 1973, 4, 1-23. [CrossRef]

22. Grimm, V.; Wissel, C. Babel, or the ecological stability discussions: An inventory and analysis of terminology and a guide for avoiding confusion. Oecologia 1997, 109, 323-334. [CrossRef] [PubMed]

23. Hector, A.; Hautier, Y.; Saner, P.; Wacker, L.; Bagchi, R.; Joshi, J.; Scherer-Lorenzen, M.; Spehn, E.M.; Bazeley-White, E.; Weilenmann, M. General stabilizing effects of plant diversity on grassland productivity through population asynchrony and overyielding. Ecology 2010, 91, 2213-2220. [CrossRef] [PubMed]

24. Jucker, T.; Bouriaud, O.; Avacaritei, D.; Coomes, D.A. Stabilizing effects of diversity on aboveground wood production in forest ecosystems: Linking patterns and processes. Ecol. Lett. 2014, 17, 1560-1569. [CrossRef] [PubMed]

25. Shannon, C. A mathematical theory of communication. Bell Syst. Tech. J. 1948, 27, 379-423. [CrossRef]

26. Yun, J.I. Visualization of Local Climates Based on Geospatial Climatology. Korean J. Agric. For. Meteorol. 2004, 6, 272-289.

27. Yun, J.I. Agroclimatic Maps Augmented by a GIS Technology. Korean J. Agric. For. Meteorol. 2010, $12,63-73$. [CrossRef]

28. Rosseel, Y. Lavaan: An R package for structural equation modeling and more. Version 0.5-12 (BETA). J. Stat. Softw. 2012, 48, 1-36. [CrossRef]

29. Chapman, R.A.; Heitzman, E.; Shelton, M.G. Long-term changes in forest structure and species composition of an upland oak forest in Arkansas. For. Ecol. Manag. 2006, 236, 85-92. [CrossRef]

30. Wang, W.; Lei, X.; Ma, Z.; Kneeshaw, D.D.; Peng, C. Positive relationship between aboveground carbon stocks and structural diversity in spruce-dominated forest stands in New Brunswick, Canada. For. Sci. 2011, 57, 506-515.

31. Liang, J.; Buongiorno, J.; Monserud, R.A.; Kruger, E.L.; Zhou, M. Effects of diversity of tree species and size on forest basal area growth, recruitment, and mortality. For. Ecol. Manag. 2007, 243, 116-127. [CrossRef]

32. Binkley, D.; Stape, J.L.; Bauerle, W.L.; Ryan, M.G. Explaining growth of individual trees: Light interception and efficiency of light use by Eucalyptus at four sites in Brazil. For. Ecol. Manag. 2010, 259, 1704-1713. [CrossRef]

33. Long, J.N.; Shaw, J.D. The influence of compositional and structural diversity on forest productivity. For. Int. J. For. Res. 2010, 83, 121-128. [CrossRef]

34. Stape, J.L.; Binkley, D.; Ryan, M.G.; Fonseca, S.; Loos, R.A.; Takahashi, E.N.; Silva, C.R.; Silva, S.R.; Hakamada, R.E.; Ferreira, J.M.d.A.; et al. The Brazil Eucalyptus Potential Productivity Project: Influence of water, nutrients and stand uniformity on wood production. For. Ecol. Manag. 2010, 259, 1684-1694. [CrossRef]

35. Fahey, R.; Fotis, A.; Woods, K. Quantifying canopy complexity and effects on productivity and resilience in late-successional hemlock-hardwood forests. Ecol. Appl. 2015, 25, 834-847. [CrossRef] [PubMed]

36. Fotis, A.T.; Curtis, P.S. Effects of structural complexity on within-canopy light environments and leaf traits in a northern mixed deciduous forest. Tree Physiol. 2017, 37, 1426-1435. [CrossRef] [PubMed]

37. Hardiman, B.S.; Gough, C.M.; Halperin, A.; Hofmeister, K.L.; Nave, L.E.; Bohrer, G.; Curtis, P.S. Maintaining high rates of carbon storage in old forests: A mechanism linking canopy structure to forest function. For. Ecol. Manag. 2013, 298, 111-119. [CrossRef] 
38. Purves, D.W.; Lichstein, J.W.; Pacala, S.W. Crown Plasticity and Competition for Canopy Space: A New Spatially Implicit Model Parameterized for 250 North American Tree Species. PLoS ONE 2007, 2, e870. [CrossRef]

39. Jucker, T.; Bouriaud, O.; Coomes, D.A.; Baltzer, J. Crown plasticity enables trees to optimize canopy packing in mixed-species forests. Funct. Ecol. 2015, 29, 1078-1086. [CrossRef]

40. Garber, S.M.; Maguire, D.A. Stand Productivity and Development in Two Mixed-Species Spacing Trials in the Central Oregon Cascades. For. Sci. 2004, 50, 92-105.

41. Forrester, D.I.; Bauhus, J. A review of processes behind diversity-Productivity relationships in forests. Curr. For. Rep. 2016, 2, 45-61. [CrossRef]

42. Bouriaud, O.; Marin, G.; Bouriaud, L.; Hessenmöller, D.; Schulze, E.-D. Romanian legal management rules limit wood production in Norway spruce and beech forests. For. Ecosyst. 2016, 3, 20. [CrossRef]

43. Schulze, E.D.; Bouriaud, O.; Weber, U.; Roscher, C.; Hessenmoeller, D.; Kroiher, F.; Schall, P. Management breaks the natural productivity-biodiversity relationship in forests and grassland: An opinion. For. Ecosyst. 2018, 5, 3. [CrossRef]

44. Forrester, D.I.; Kohnle, U.; Albrecht, A.T.; Bauhus, J. Complementarity in mixed-species stands of Abies alba and Picea abies varies with climate, site quality and stand density. For. Ecol. Manag. 2013, 304, $233-242$. [CrossRef]

45. Hunt, M.A.; Unwin, G.L.; Beadle, C.L. Effects of naturally regenerated Acacia dealbata on the productivity of a Eucalyptus nitens plantation in Tasmania, Australia. For. Ecol. Manag. 1999, 117, 75-85. [CrossRef]

46. Del Río, M.; Sterba, H. Comparing volume growth in pure and mixed stands of Pinus sylvestris and Quercus pyrenaica. Ann. For. Sci. 2009, 66, 1-11.

47. Tilman, D. Biodiversity: Population versus ecosystem stability. Ecology 1996, 77, 350-363. [CrossRef]

48. de Mazancourt, C.; Isbell, F.; Larocque, A.; Berendse, F.; De Luca, E.; Grace, J.B.; Haegeman, B.; Wayne Polley, H.; Roscher, C.; Schmid, B.; et al. Predicting ecosystem stability from community composition and biodiversity. Ecol. Lett. 2013, 16, 617-625. [CrossRef]

49. Tilman, D.; Isbell, F.; Cowles, J.M. Biodiversity and Ecosystem Functioning. Annu. Rev. Ecol. Evol. Syst. 2014, 45, 471-493. [CrossRef]

50. Cleve, K.V.; Oliver, L.; Schlentner, R.; Viereck, L.A.; Dyrness, C. Productivity and nutrient cycling in taiga forest ecosystems. Can. J. For. Res. 1983, 13, 747-766. [CrossRef]

51. Vitousek, P.M.; Sanford, R.L., Jr. Nutrient cycling in moist tropical forest. Annu. Rev. Ecol. Syst. 1986, 17, 137-167. [CrossRef]

52. Ulrich, B. A concept of forest ecosystem stability and of acid deposition as driving force for destabilization. In Effects of Accumulation of Air Pollutants in Forest Ecosystems; Springer: Dordrecht, The Netherlands, 1983; Volume 29.

(C) 2019 by the authors. Licensee MDPI, Basel, Switzerland. This article is an open access article distributed under the terms and conditions of the Creative Commons Attribution (CC BY) license (http://creativecommons.org/licenses/by/4.0/). 